\title{
Advanced Techniques of Saponite Recovery from Diamond Processing Plant Water and Areas of Saponite Application
}

\author{
Valentine A. Chanturiya ${ }^{1}$, Vladimir G. Minenko ${ }^{1}$, Dmitriy V. Makarov ${ }^{2, *}$, Olga V. Suvorova ${ }^{3}$ \\ and Ekaterina A. Selivanova ${ }^{4}$ (D) \\ 1 Institute of Comprehensive Exploitation of Mineral Resources of the Russian Academy of Sciences, \\ Kryukovsky Tupik, 4, 111020 Moscow, Russia; vchan@mail.ru (V.A.C.); vladi200@mail.ru (V.G.M.) \\ 2 Institute of North Industrial Ecology Problems, Kola Science Centre of the Russian Academy of Sciences, \\ Fersman St., 14a, 184209 Apatity, Russia \\ 3 I.V. Tananaev Institute of Chemistry and Technology of Rare Elements and Mineral Raw Materials, Kola \\ Science Centre of the Russian Academy of Sciences, Fersman St., 26a, 184209 Apatity, Russia; \\ suvorova@chemy.kolasc.net.ru \\ 4 Geological Institute, Kola Science Centre of the Russian Academy of Sciences, Fersman St., 14, 184209 \\ Apatity, Russia; selivanova_e_a@mail.ru \\ * Correspondence: mdv_2008@mail.ru; Tel.: +7-81555-79-3-37
}

Received: 22 October 2018; Accepted: 22 November 2018; Published: 26 November 2018

\begin{abstract}
Methods of cleaning and processing of saponite-containing water from diamond processing plants in the Arkhangelsk region, Russia, are discussed. The advantages of electrochemical separation of saponite from process water enabling to change its structural-texture, physico-chemical and mechanical properties are demonstrated. Possible areas of saponite and modified-saponite products application are considered.
\end{abstract}

Keywords: saponite-containing waters; diamond processing plants; cryogenic treatment; electrochemical separation; saponite product applications

\section{Introduction}

The Lomonosov diamond deposit (Archangelsk province, Russia) currently contains 10 kimberlite pipes. Before launching quarrying operations, it is necessary to extract about 300 million tons of diamond-bearing ore and barren rock [1,2]. Almost all rock in the deposit pipes is represented by clay minerals, mostly saponite, the share of which reaches $90 \%$ in the vent facies [1].

Saponite belongs to the smectite group and is characterized by high physico-chemical activity and low density in aqueous media due to its tendency to hydrate. When in an aqueous medium, saponite disperses, forming a suspension, hindering the managing of both the tailing ponds and water circulation at the processing plants (Figure 1). 


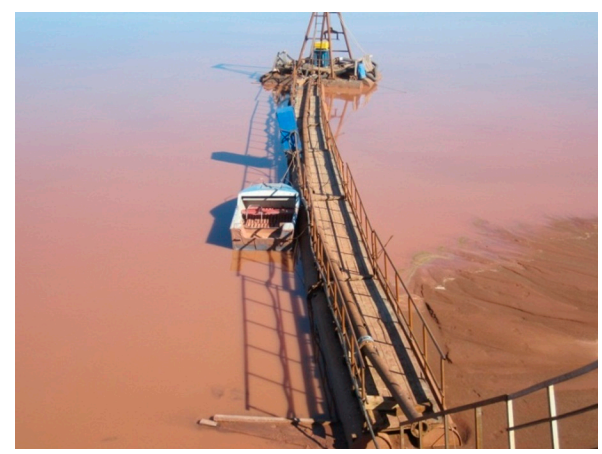

Figure 1. Tailing pond of processing plant, Lomonosov GOK, Severalmaz JSC. Reproduced with permission from the author, V.I. Bogachev.

Therefore, searching, validating and developing effective techniques for recovery of saponite-containing water at diamond processing plants is a current issue. The immediate objective is to develop an effective water rotating system, which will boost diamond recovery, reduce the ecological stress, and open ways for manufacturing of target-oriented saponite-containing products for multi-sector applications.

\section{Structure and Properties of Saponite}

The structure and properties of saponite, which are highly attractive for the industry, are described in detail in textbooks, reference books, and professional reports. According to the International Mineralogical Association (IMA) list [3], the saponite mineral consists of the formula $(\mathrm{Ca}, \mathrm{Na})_{0.3}(\mathrm{Mg}, \mathrm{Fe})_{3}(\mathrm{Si}, \mathrm{Al})_{4} \mathrm{O}_{10}(\mathrm{OH})_{2} \cdot 4 \mathrm{H}_{2} \mathrm{O}$; it is one of the three most common members in the smectite group, along with montmorillonite and nontronite [4].

Like all smectites, saponite has unique physical and chemical properties that arouse scientific interest, namely, high cation exchange capacity, swelling and rheological properties, hydration and dehydration, high plasticity, bonding capacity, and the ability to react with inorganic and organic reagents [5]. These properties are the results of:

-the layered nature of the crystal structure containing weakly bound cations;

-a wide range of chemical composition variations;

-extremely small particle size, flat shape and, accordingly, great surface area.

\subsection{Crystal Structure}

The basic structure of smectite group minerals is well known and has been illustrated in many publications (one of them is shown in Figure 2). Smectites are three-layer minerals. This three-layer package has two silica tetrahedral sheets joined to a central octahedral sheet. On this basis, smectite structures can be classified as 2:1 phyllosilicates. Due to substitutions in the tetrahedral or octahedral sheets, or the existence of vacancies in the octahedral sheet, the surface of the three-layer package has a negative charge, which creates a charge imbalance.

According to the Nomenclature Committee of the Association Internationale pour l'Etude des Argiles (AIPEA) [6] the layer charge of smectites varies from 0.2 to 0.6 electrons per half unit cell (e/h.u.c.). The layer charge is balanced by the interlayer cations $\mathrm{Na}, \mathrm{Ca}, \mathrm{K}, \mathrm{Mg}$, $\mathrm{Fe}$, which are weakly bonded and exchangeable. The interlayer space contains water molecules. The number of molecules is not constant and may increase depending on the grade of the interlayer cation, causing the mineral particle to swell. The interlayer space also contains water molecules in varying quantities, which may increase depending on the interlayer cation kind and cause the layers to distend and the mineral particles to swell. Indeed, it has been shown that the layer charge is related to the colloidal properties of smectites such as swelling. Charge heterogeneity, which includes both charge magnitude and charge localization, is also related to these properties [7]. 
Saponite belongs to the trioctahedral series of minerals of the smectite group. Notwithstanding both the wide occurrence of saponite in nature and extensive previous study, the saponite structure has not been determined yet. The authors are of the opinion that the reason for it is the absence of material applicable for single-crystal investigations.

\subsection{Chemical Composition and Properties}

The chemical composition of naturally occurring saponite is highly variable due to common $\mathrm{Fe}^{2+}$, $\mathrm{Fe}^{3+}$ and $\mathrm{Al}^{3+}$ substitutions for $\mathrm{Mg}^{2+}$ in the octahedral sheet, which are accompanied by partial $\mathrm{Al}^{3+}$ and $\mathrm{Fe}^{3+}$ substitutions for $\mathrm{Si}^{4+}$ in the tetrahedral sheet $[8,9]$. Thus, saponite from the Arkhangelsk kimberlite province contains $5.09 \% \mathrm{Al}_{2} \mathrm{O}_{3}, 3.14 \% \mathrm{Fe}_{2} \mathrm{O}_{3}$ and $2.56 \% \mathrm{FeO}$ [10]; crystal-chemical formula, calculated on 22 charges, is the following: $\left(\mathrm{Ca}_{0.1}, \mathrm{Na}_{0.1}, \mathrm{~K}_{0.1}\right)_{0.3}\left(\mathrm{Mg}_{2.6}, \mathrm{Fe}^{2+}{ }_{0.1}, \mathrm{Fe}^{3+}{ }_{0.2}\right)_{2.9}\left(\mathrm{Si}_{3.6}, \mathrm{Al}_{0.4}\right)_{4} \mathrm{O}_{10}(\mathrm{OH})$ $2.8 \mathrm{H}_{2} \mathrm{O}$.

Saponite is different from other smectites because a part of the negative tetrahedral charge is balanced by substitution of octahedral $\mathrm{Mg}^{2+}$ by trivalent cations $\mathrm{Al}^{3+}$ or $\mathrm{Fe}^{3+}$, i.e., the octahedral sheet bears a positive charge. However, the tetrahedral charge, due to substitution of $\mathrm{Si}^{4+}$ by $\mathrm{Al}^{3+}$, is much greater and outbalances any possible positive octahedral charge [11].

These substitutions, their quantity and cation kind essentially affect the mineral's properties. Moreover, the mineral's properties are further changed when the iron, present in the mineral as an isomorphous impurity, varies its oxidation degrees in response to certain conditions.

Fairly often, the composition of natural saponite is heterogeneous and, like all smectites and other layered silicates, it may contain fragments of other layered silicates, forming sometimes mixed-layer structures. Saponite is commonly found in association with montmorillonite or talc [12-14]. According to the authors of [14], mixed-layered aggregates of this type have a greater surface area (up to $283 \mathrm{~m}^{2} / \mathrm{g}$ ) and a high concentration of mesopores comparable with quality sorbents.

In order to obtain a chemically- and phase-wise homogeneous composition, saponite is synthesized to achieve controllable properties, the surface charge distribution in the first place [15-17]. One recent example is the use of synthetic saponites as hydro processing catalyst components, described in a patent of Chevron Corp [18]. The growing interest in synthesis methods over the past decade has been generated by the competitive advantages of synthetic saponite, namely, its mesoporosity, controllable acidic and basic properties, and stability $[19,20]$.

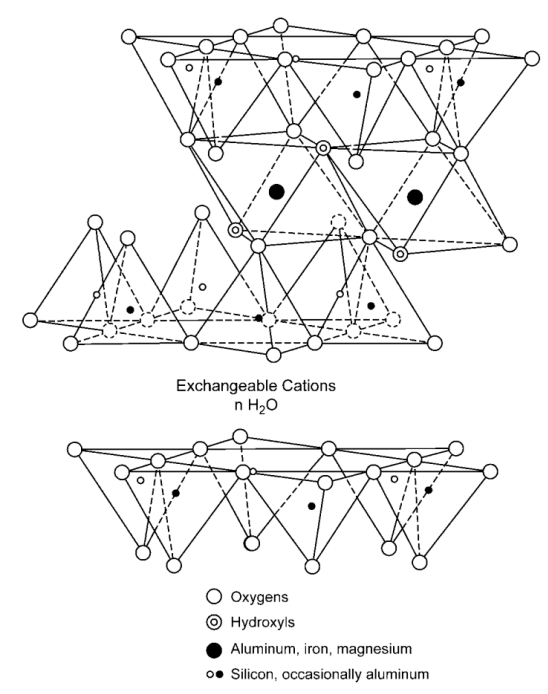

Figure 2. Schematic diagram of smectite structure [21].

Being weakly bonded with the structure packages, the interlayer cations $\mathrm{Na}, \mathrm{Ca}, \mathrm{K}, \mathrm{Mg}$ can be easily removed from it, or substituted for other cations, without destroying the three-layer package. 
Traditionally, the cations are removed via acid treatment. Researching in the area of acidic modification of saponite is also provoked by the possibility of altering the coordination of octahedral cations to the extent of obtaining a separate silicate layer with a super-high surface area [22-25].

In the case of trioctahedral saponite, the conditions providing an almost complete removal of the octahedral layer with resulting surface increase of up to $300 \mathrm{~m}^{2} / \mathrm{g}$ and microporosity are rather mild [26].

There is no evidence of studies of the sorption mechanism of natural saponite, but some results have been reported on the sorption of saponite-containing products [27,28].

Regarding thermal properties, the Arkhangelsk saponite is close to other smectites [10]. Differences can be observed in the area of the second endothermic effect, which is attributable to cation substitutions in the octahedral layer.

There is a unique property of smectite crystals that has been widely researched [29]. It consists in increasing, or decreasing, of the number of water molecules between the layers from 0 to 4 , causing the basal distance to increase from 10 to $22 \AA$. Swelling occurs in polar organic solvents as well. The layer charge effect, produced on the swelling, has been fairly well researched [7], but no studies on saponite swelling have been reported yet.

Investigating of smectite-water suspensions is by far more difficult. Usually, smectites form fine crystals of size $0.5 \mu \mathrm{m}$. When in small concentrations, the suspensions have Newtonian properties created by hydrodynamic forces, whereas at increasing concentrations, the inter-particle interactions trigger non-Newtonian behavior. The variety of interactions caused by electrostatic and electrokinetic characteristics is of great current interest (see, for instance, [5]). Saponite is the least studied among the smectites, even though it is also known to possess high and ambiguous electrokinetic potential values in aqueous suspensions [30].

\section{Techniques of Circulating Water Clarification and Obtaining of Thickened Saponite Product}

Nowadays the rate of saponite particles precipitation and sediment compaction is increased by using reagent and cryogenic treatment, bubbling with carbon dioxide, and exposure to acoustic, electric and magnetic fields [1,31-34].

K.M. Asonchik, A.V. Utin and coauthors have proposed carbonizing to accelerate clearing of the slurry tailings and circulating water at the diamond processing plant of the Lomonosov GOK, Severalmaz JSC (DPP LGOK) [31,32]. The method incorporates the interaction of pure carbon dioxide with saponite-containing water to produce carbonic acid, which further interacts with the saponite calcium and magnesium compounds and forms water-soluble hydrocarbonates $\mathrm{Mg}\left(\mathrm{HCO}_{3}\right)_{2}$ and $\mathrm{Ca}\left(\mathrm{HCO}_{3}\right)_{2}$. According to the authors, the passing of calcium and magnesium ions to the solution promotes destruction of the colloid structure, thus purifying the water.

During a pilot testing of the technology at DPP LGOK, the water was clarified to less than $0.5 \mathrm{mg} / \mathrm{dm}^{3}$ of solids. It should be noted, however, that the initial solid content in the experiments did not exceed $110 \mathrm{~g} / \mathrm{dm}^{3}$ and became $158 \mathrm{~g} / \mathrm{dm}^{3}$ in the thickened slurry after four days of settling [31,32], whereas the natural settling of dumped water samples with initial solids contents of $50-100 \mathrm{~g} / \mathrm{dm}^{3}$ takes seven or more days. Gravity separation yields clarified water and a precipitate containing less than $5 \mathrm{~g} / \mathrm{dm}^{3}$ and up to $200 \mathrm{~g} / \mathrm{dm}^{3}$ of solids, respectively [7,8].

In 2013, S.A. Bakharev conducted at DPP LGOK a commercial testing of a unit producing a complex acoustic impact on circulating water (CAIP-CW). The geometric size of the pond was $307 \times 37 \times 3.7 \mathrm{~m}$ [33]. Prior to commercial testing, the circulating water was highly turbid, both in the lower pond horizon, representing the settling area, and at the outlet of discharge pipes. In the middle horizon $(0.4 \mathrm{M})$, the slime particles concentration was about $3.31 \mathrm{~g} / \mathrm{dm}^{3}$; in the upper horizon $(0.2 \mathrm{M})$ it was $1.26 \mathrm{~g} / \mathrm{dm}^{3}$. The CAIP-CW testing showed a much greater diminishing of water turbidity compared to gravity clarification: the slime particle concentrations in the middle and upper horizons became, respectively, $0.32 \mathrm{~g} / \mathrm{dm}^{3}$, and $0.16 \mathrm{~g} / \mathrm{dm}^{3}$. 
The results of the acoustic method of thickening of saponite-containing precipitate at CAIP-CW are of practical importance because it makes possible the extraction and recycling of saponite. Using the reagent-free (acoustic) method of thickening of saponite-containing precipitate helped increase the particles' concentration in the precipitate from 89 to $743-790 \mathrm{~g} / \mathrm{dm}^{3}$. The precipitate structure was similar to modeling clay.

However, the report [33] does not describe the experimental conditions of the saponite-containing precipitate thickening method. In addition, the high solids values in the resulting saponite-containing products $\left(743-790 \mathrm{~g} / \mathrm{dm}^{3}\right.$ at a power consumption of $0.5 \mathrm{~W} / \mathrm{m}^{3}$ of the slurry) are untypical of hygroscopic saponite, which may indicate the presence of high quartz, dolomite and other mineral contents in the samples. Unfortunately, the author does not disclose the results of mineralogical analyses of the precipitates. Besides, the data on sieve composition of the initial and resulting products, presented by the author [33], seem questionable due to the small size of pure saponite particles (less than $7 \mu \mathrm{m}$ ) and, which is worse, of the obtained precipitates, because when the content of the highly hygroscopic saponite is $400 \mathrm{~g} / \mathrm{dm}^{3}$, the suspension turns viscous and non-flowing. Therefore, the sieve analysis of precipitates with saponite contents of $743-790 \mathrm{~g} / \mathrm{dm}^{3}$ is likely to have been achieved only after repeat diluting with water and vigorous stirring, which must have resulted in destruction of the floccules believed to be forming by the author.

The authors of works $[1,34]$ have tested some unconventional techniques, including cryogenic treatment, applicable in clarification of circulating water at diamond treatment plants. Cryogenic treatment incorporates freezing and defrosting of a saponite suspension. The diffusion layer of the particles, which prevents particle convergence, is destroyed, initiating the saponite sediment genesis. The key factor to be observed is the frosting-defrosting regime. The precipitate is the densest at a slow rate, providing the draining of separating moisture. The precipitate carcass density achieves 0.74 $\mathrm{g} / \mathrm{dm}^{3}$, which is 4 -fold higher than that of the initial suspension. Furthermore, the resulting precipitate, as believed by the author of work [1], acquires the ability to further diagenetic alterations, because the increase of gravity loads promotes the growth of the number and area of contacts between the particles, which strengthens the precipitate structure.

Figure 3 presents the general layout of a tailing pond with cryogenic treatment [1,35]. It can be seen that beyond the main pond and the protecting dam is located a pond of clarified water. After saponite sedimentation, the water flows through a drainage installation in the bottom part of the main tailing pond to the clarified water pond, where it accumulates for reverse water supply. The tailing pond is divided into two sections by a dam. One section receives the pulp and accumulates the saponite suspension; the other is used for freezing of suspension in winter and draining of thawed out water during the summers. The freezing-defrosting process promotes the sedimentation of saponite, which is extracted from the pond, pumped, and stored in a specially arranged storage representing depressions in natural relief. After being emptied, this section of the tailing pond is ready to be filled with the pulp again, while the accumulated suspension will be freezing in the other section. The cycle is repeated so that every year the pond sections change places.

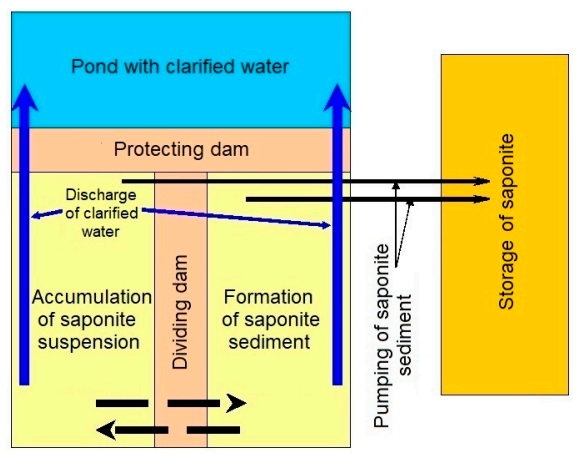

Figure 3. Layout of a tailing pond with cryogenic treatment. Reproduced with permission from F.S. Karpenko [1]. 
The efficiency of reagent application in saponite sediment thickening was experimentally tested by F.S. Karpenko [1], who used 18 various flocculants and inorganic coagulating agents $\mathrm{AlCl}_{3}$ and $\mathrm{Al}_{2} \mathrm{SO}_{4}$ and also examined the effect of electric and magnetic fields on saponite precipitation and thickening. As a result of reagent use, the saponite settling rate was increased several hundred-fold, but this neither increased the density nor reduced the porosity of the precipitate so that it differed (slightly) from natural sediment. What is more, the precipitate in the experiments was unstable, forming a water suspension if stirred. It should also be remembered that the quantity of flocculating and coagulating agents consumed was considerable (up to $180 \mathrm{~g} / \mathrm{t}$ and to $150 \mathrm{~g} / \mathrm{t}$, respectively). The most effective of the tested reagents were anionic flocculants of the series Praestol 2540 and Magnafloc 156 , which provided a precipitation rate of $30 \mathrm{~cm} / \mathrm{h}$ and a maximum carcass density of $0.24 \mathrm{~g} / \mathrm{cm}^{3}$.

Using the electric and magnetic fields for saponite precipitate settling and thickening proved to be ineffective [1].

The above-discussed process questions the efficiency of both reagent treatment, bubbling with carbon dioxide and acoustic impact at high content (over $50-100 \mathrm{~g} / \mathrm{dm}^{3}$ ) of fine slimes. What is more, none of the above-mentioned methods allow varying of the precipitate's mineral composition.

In works [36-40], a reagent-free electrochemical method and implementation for saponite recovery from diamond-treatment plant process water is reported (Figure 4). The designed electrochemical separators accommodate the processes of electrophoretic extraction of saponite-containing product at the anode and osmic evolution of water at the cathode. The obtained concentrate (electrochemically modified saponite) is characterized by high contents of solids (up to $620 \mathrm{~g} / \mathrm{dm}^{3}$ of suspension) and saponite and montmorillonite (more than 74.5\%) and low quartz and dolomite contents (less than $12 \%$ and $5 \%$, respectively), compared to the initial saponite-containing product $(60-68 \%, 14-20 \%$, and 6-10\%, respectively). Owing to its chemical composition $\left(\mathrm{SiO}_{2}, \mathrm{Al}_{2} \mathrm{O}_{3}, \mathrm{CaO}, \mathrm{Fe}_{2} \mathrm{O}_{3}, \mathrm{FeO}, \mathrm{TiO}_{2}, \mathrm{Na}_{2} \mathrm{O}\right.$, $\mathrm{K}_{2} \mathrm{O}, \mathrm{SO}_{3}$ etc. as main components), denser packing, high content of smectite group minerals and the presence of exchangeable cations, the modified saponite-containing product can be used in the manufacturing of quality building materials and sorbents [41].

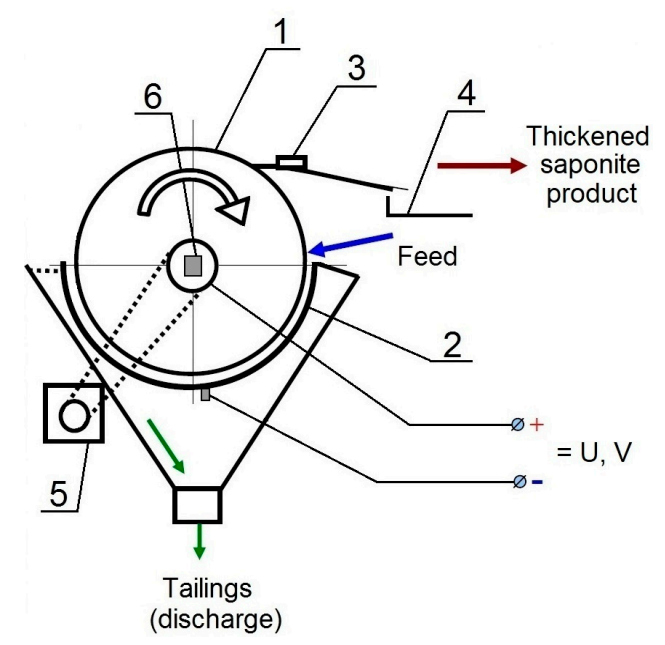

Figure 4. Schematic diagram of the electrochemical separator. 1—drum; 2-separating bath; 3-scraper; 4-chute; 5-engine; 6-current-collecting device.

It is evident that the most effective techniques for obtaining and thickening of saponite precipitate are cryogenic treatment and electrochemical separation. However, the former has the drawbacks of seasonal use and likely dispersion of defrosting of saponite-containing product by melting water. 


\section{Range of Saponite Product Applications}

Saponite has been actively researched in recent years [42-94] as a valuable product with unique properties and a wide range of applications, including the chemical, food and consumer goods industries, agriculture, medicine and pharmacology, foundry practices, metallurgy, and construction.

\subsection{Application of Saponite in Agriculture}

Much of the research has been devoted to utilizing saponite in agriculture, livestock husbandry, and veterinary as an active or suspending agent and mineral additive to fodder [42-48].

The authors of $[44,45,48]$ have developed a compound for pre-sowing treatment of winter wheat incorporating the raxil pesticide-a $2 \%$ wettable powder and saponite, i.e., saponite-based thixotropic water suspensions for plant protection, and a method of improving the agrochemical performance of ammonium saltpeter, whereby saponite as a mineral adsorbent is added in $2 \%$ per mass of the ready product.

Inventions reported in $[46,47]$ present the processes of manufacturing of cattle fodder admixed with saponite, and also a KANIR-3 amide-concentration mineral additive based on grain offal and carbamide admixed with saponite, potato starch, and sodium sulfate.

Thus, the Ukraine standards $[42,43]$ establish the general technical requirements for the quality of saponite flour as an integral-action ameliorant-a magnesium-containing fertilizer produced from saponite clay with high magnesium content (up to $12 \%$ ) [41], and also to the quality of saponite-containing polymineral preparations used as additives to broiler-chick fodder [43].

\subsection{Application of Saponite in Cosmetics Industry}

Saponite is now used as an ingredient in the manufacturing of cosmetics and preparations, hygiene, deterging, and bleaching materials [49-57].

Research works $[49,50]$ have been proposed some cosmetic composites containing clay mineral powders (talc, kaolin, saponite, mica, etc.), treated by fluorine, and an almost water-free oily component. The share of the clay minerals in the cosmetic product varies between 0.5 to $50 \%$.

The authors of [51-55] have developed the following preparations: facial cosmetics containing an ultraviolet adsorbent with $0.001-0.005 \% \mathrm{~mol}$ per $10 \mathrm{~g}$ of a clay mineral, such as saponite; a cosmetic composition for skin and hair care based on water-soluble derivatives of chitin, clay minerals and intercalated clay; cosmetic deodorants containing up to $40 \mathrm{wt} \%$ of clay minerals (saponite, montmorillonite, beidellite, kaolin, etc.). These cosmetic hair, scalp and/or skin detergents (shampoos and shower gels) contain up to $50 \%$ of detergents (surface-active materials), 0.001 to $5 \%$ of insoluble conditioning agents and up to $15 \%$ of clay [55].

The authors of $[56,57]$ report a water-softening reagent for household washing and dishwashing machines based on fine-crystal zeolite $(50-70 \%)$, clay minerals $(2-10 \%)$ such as saponite, montmorillonite and hectorite, a sodium salt of (co) polymeric carboxylic acid (5-15\%), sodium sulfate $(1-10 \%)$, an organic surface-active material (0-3\%), and water. A method for the production of a bleaching agent consisting of a bleaching activator; an inorganic bonding substance (montmorillonite, saponite or hectorite with an ion-exchange capacity of 50-100 meq/100 g) has also been proposed.

\subsection{Application of Saponite in Pharmaceutical Industry}

Works [58-60] demonstrate the possibility of medicine-related applications of saponite, such as in the manufacturing of drugs and medications.

The authors of [58] have proposed a method for the manufacturing of $\alpha$-tocopherol derivatives used as antisterile vitamins, anticholesterol agents boosting blood flow, antioxidants, etc. Tocopherol derivatives can be commercially manufactured using saponite, bentonite or montmorillonite as catalysts, in which the mobile cations are substituted for one of the following metals: scandium, yttrium, aluminum, iron, tin, copper, titanium, zinc, nickel, gallium, or zirconium. 
Work [59] describes a method for the production of a clay mineral containing an IB-group metal $(\mathrm{Au}, \mathrm{Ag}, \mathrm{Cu})$ intercalated into it by the contact of a clay aqueous dispersion (0.5-6.0\%) with a cation-exchange resin stoichiometrically associated with an IB-group metal ion. The method provides substituting of over 30\% of exchange cations in the clay mineral for an IB-group metal. For instance, an Ag-containing clay material is used as a basic component or thickener for coating materials with antifungal properties.

The authors of work [60] have proposed a manufacturing method of antimicrobial nano-size clay inhibiting the growth and proliferation of microorganisms by substituting the clay interlayer cations for an alkylamine. Clay of this kind can prevent the adverse health impact of microorganisms such as malignant bacteria and fungi. Manufacturing of the antimicrobial nano-size clay includes the following stages: Dispersing of nanoparticles of clay mineral, such as montmorillonite, saponite, hectorite, etc. in organic acid solutions, obtained by adding an organic solvent (ethanol, methanol, isopropyl alcohol, acetone, dimethylformamide, dimethylsulfoxide, or N-methylpyrrolidone) to a solution containing distilled water and chlorohydric acid; adding of alkylamine; filtering and drying of the obtained product.

\subsection{Application of Saponite in Various Technology Processes}

Saponite is known [61-74] to be used in various technological processes as an ingredient of sorbents, catalysts, carrying agents, thickeners and pigments, either in natural or activated form.

M.K. Uddin presented a survey of research of clay materials as heavy-metal adsorbents, carried out mostly in 2006-2016 [61]. The work describes the structure, classification and chemical composition of different clay minerals and analysis of their adsorption behavior. Although analysis of previous studies has confirmed the effectiveness of both natural and modified clay minerals in water treatment from heavy metal ions, the author considers that further research is needed on the modification and synthesis of new clay materials for adsorbing of dissimilar pollutants from the environment.

The $\mathrm{Cu}^{2+}$ ions removal from aqueous solutions by using natural and acid-activated clays is reported in work [62]. The adsorption isotherms, process kinetics and thermodynamics have been investigated. Interacting of the $\mathrm{Cu}^{2+}$ ions with clays and their acid-activated species was studied in an equilibrium batch process. The experiments were conducted at varied $\mathrm{pH}$, interaction time, $\mathrm{Cu}^{2+}$ ion concentrations, clay quantities, and temperatures. The clays had a satisfactory adsorption ability of Langmuir monolayer of 9.2-10.1 mg/g; the acid-activated clays-31.8-32.3 mg/g. The interactions were endothermic, promoting the entropy increment and decreasing of the Gibbs energy. Adsorption of the $\mathrm{Cu}^{2+}$ ions on clay surface is unlikely to seriously affect the surface configuration, but the noticeable entropy change may be linked to increasing of randomness state, with $\mathrm{Cu}^{2+}$ ions taking up positions on the solid surface. Major structural changes and adjustments in the adsorbent surface structure may be ruled out. However, the surface structure might have been affected by the release of ions such as $\mathrm{H}^{+}$and $\mathrm{K}^{+}$from the clay surface to solution and also by partial desolvation of the metal ions. Thus, although the interactions were endothermic, they were driven by a positive entropy change [62].

Unlike untreated clay minerals, the acid-activated ones acquire a greater adsorption capacity due to developed surface area and greater pore volume. The $\mathrm{Cu}^{2+}$ ions release is affected by solution $\mathrm{pH}$; as $\mathrm{pH}$ increases, the quantity of adsorbed matter increases to the point when the ions begin to precipitate as insoluble hydroxides at $\mathrm{pH}$ higher than 6.0. Adsorption of $\mathrm{Cu}^{2+}$ ions is precipitous at the onset of the substance-adsorbent interaction. The process kinetics is highly complicated and, although the authors have applied different kinetic models, they failed to draw a definite conclusion about the process rate mechanisms. It is highly probable, however, that the adsorption follows a second-order process. The validity of Langmuir isotherm in relation to the $\mathrm{Cu}^{2+}$-clay interactions suggests that the $\mathrm{Cu}^{2+}$ ions are largely retained at the clay surface owing to chemical reactions.

Work [63] demonstrates the performance of mechanically and chemically activated saponite as $\mathrm{Cu}^{2+}$ and $\mathrm{Ni}^{2+}$ ions adsorbent from aqueous solutions. Saponite was activated via high-energy grinding in a planetary ball mill. Its structure was profoundly changed by the mechanical stresses of 
high-energy grinding, creating an active $\mathrm{Mg}-\mathrm{OH}$ surface with a high acid neutralization. Activated saponite is a better adsorbent of $\mathrm{Cu}^{2+}$ ions as $\mathrm{Cu}(\mathrm{OH})_{2}$ than of $\mathrm{Ni}^{2+}$. As a result of activation, the maximum removal capacity of saponite in relation to $\mathrm{Cu}^{2+}$ ions increased from 33.2 to $287 \mathrm{mg} / \mathrm{g}$, whereas for $\mathrm{Ni}^{2+}$ ions it increased from 46.0 to $124 \mathrm{mg} / \mathrm{g}$. It has been established that the adsorbed metal ions form insoluble hydroxides on the saponite surface and are therefore inaccessible to further ion exchange. The formation of insoluble $\mathrm{Cu}(\mathrm{OH})_{2}$ was confirmed by XRD and SEM analysis, and the formation of $\mathrm{Ni}(\mathrm{OH})_{2}$ - by SEM analysis. This research has illustrated the feasibility of smectites modification and usability in purification of heavy metal-contaminated process water.

As discovered by V.G. Minenko et al. [64], the saponite-containing product, obtained via electrochemical separation of process water, is characterized by high sorption capacity in relation to $\mathrm{Ni}^{2+}$ and $\mathrm{Cu}^{2+}$ ions (40 and $90 \mathrm{mg} / \mathrm{g}$, respectively). After calcining at $750{ }^{\circ} \mathrm{C}$, the sorption capacity increases to 189 and $224 \mathrm{mg} / \mathrm{g}$, respectively. The metal-containing phases were diagnosed and the metals' sorption mechanism was validated using the XRD and SEM with EDS. The product thermally activated at $750{ }^{\circ} \mathrm{C}$ was successfully tested in nickel and copper solutions (50 and $250 \mathrm{mg} / \mathrm{dm}^{3}$, respectively) with resulting solution concentrations of 0.01 and $0.001 \mathrm{mg} / \mathrm{dm}^{3}$, respectively, meeting the maximum admissible concentration requirements to fishery water.

The method proposed in patent [65] describes the ion adsorption of $\mathrm{Cr}^{6+}$ on natural ferro-saponite followed by $\mathrm{Cr}^{6+}$ reduction and is aimed at removal of $\mathrm{Cr}^{6+}$ from water. The method incorporates the interaction of $0.04 \mathrm{M}$ potassium dichromate solutions with natural ferro-saponite clays at 50 to $200{ }^{\circ} \mathrm{C}$ during 1 to $3.0 \mathrm{~h}$.

Work [66] has demonstrated that the saponite-based sorption technique can be applied in purification of uranium-contaminated water (over 90\%). Equilibrium in the $\mathrm{U}^{6+}$-saponite system was found to be established within $8 \mathrm{~h}$. The saponite- $\mathrm{pH}$ relationship has a clear maximum at $\mathrm{pH}$ 5-7 (Figure 5). The isotherm of $\mathrm{U}^{6+}$ sorption on saponite is described by the Langmuir empirical equation. The sorption process was shown to be affected by complexing reagents (ethylenediaminetetraacetic acid-EDTA, carbonate ions and fulvic acids).

Intercalating of $\mathrm{Eu}^{3+}$ ions into the interlayer space of a layered silicate (magadiite) occurred via the ion-exchange reactions between magadiite and europium chloride [67]. As indicated by both the X-ray diffraction and elemental analyses, the $\mathrm{Eu}^{3+}$ cations were intercalated into the magadiite interlayer space. The ion exchange between $\mathrm{Eu}^{3+}$ and $\mathrm{Na}^{+}$occurred preferentially so that the adsorbed $\mathrm{Eu}^{3+}$ amounts were controlled quantitatively. Due to intercalated $\mathrm{Eu}^{3+}$, the resulting compounds were photo-luminescent. The luminescence intensity was directly dependent on the amount of $\mathrm{Eu}^{3+}$ absorbed. The intensity was also affected by heat treatment, corresponding to the changing environment of adsorbed $\mathrm{Eu}^{3+}$ caused by elimination of adsorbed water molecules and hydroxyl groups.

The authors of [68] report the results of quantitative determination and comparison of reactive properties of bentonite clays FEBEX and MX-80 and saponite in creating geochemical barriers and europium immobilization. (Hydrothermal treatment was performed using $\mathrm{Eu}\left(\mathrm{NO}_{3}\right)_{3}\left(\left({ }^{151} \mathrm{Eu}\right.\right.$ and ${ }^{153} \mathrm{Eu}$, with $\left.52.2 \%{ }^{153} \mathrm{Eu}\right)$ ) and radioactive ${ }^{152} \mathrm{Eu}$ for quantitative assessment of reactions.) Saponite proved to be a better barrier material than bentonite. The calculations have shown that with the use of saponite, FEBEX and MX-80 at $200{ }^{\circ} \mathrm{C} \leq \mathrm{T} \leq 350{ }^{\circ} \mathrm{C}$ europium will be immobilized within 8.5 months and at $80{ }^{\circ} \mathrm{C} \leq \mathrm{T} \leq 200{ }^{\circ} \mathrm{C}$-within several years. The reaction rate was not affected by the clay type, but the immobilizing ability of bentonite was lower than that of saponite. 


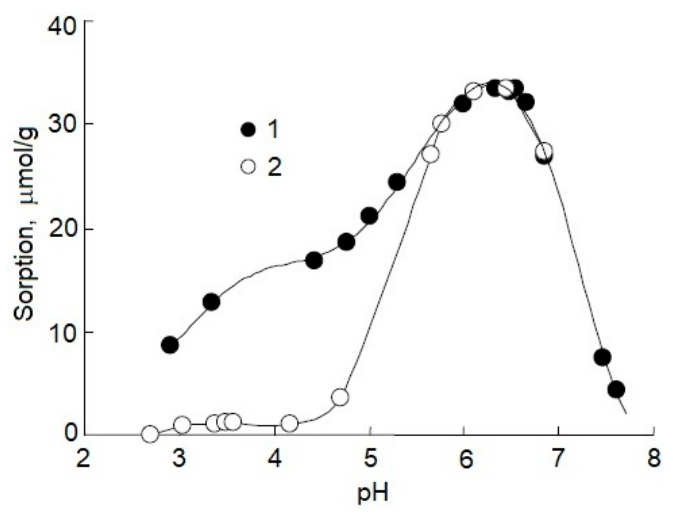

Figure 5. $\mathrm{U}^{6+}$ sorption on saponite vs the solution $\mathrm{pH}$ (ionic force $\left(\mathrm{NaClO}_{4}\right)$ 0.01(1); 0.1 (2); $\left.\mathrm{C}\left(\mathrm{U}^{6+}\right)=10^{-4} \mathrm{M} ; \mathrm{m}=0.1 \mathrm{~g} ; \mathrm{V}=50 \mathrm{~cm}^{3}\right)$ Reproduced with permission from G.N. Pshinko et al. [66].

Technology using a composite and composite-based catalyst is proposed in work [69]. The composite consists of laminated clay homogeneously dispersed in an inorganic oxide matrix. The clayish dispersion is arranged so that to totally enclose the clay layers by the matrix. The inorganic oxide was selected from a group consisting of $\mathrm{Al}_{2} \mathrm{O}_{3}, \mathrm{TiO}_{2}, \mathrm{SiO}_{2}, \mathrm{ZrO}_{2}, \mathrm{P}_{2} \mathrm{O}_{5}$ and their mixtures. The clay share is $5 \mathrm{wt} \%$ to $80 \mathrm{wt} \%$ of the composite. The clays used in the composite were saponite, montmorillonite, etc. The product can be applied as a catalyst in alkylation or hydrocracking.

The patent in [70] presents a process of glycerol polymers with the saponite catalyst. In broader terms, this invention refers to mineral polymerization techniques, including glycerol and its derivatives. The process incorporates the heating of a mineral in the presence of at least one magnesium saponite clay catalyst in the "H-form" to achieve polycondensation until glycerol polymers or its derivatives are formed. The " $\mathrm{H}$-form" saponite catalyst is obtained in the ion-exchange process via substituting the $\mathrm{Na}^{+}$ions for $\mathrm{H}^{+}$and $\mathrm{NH}_{4}{ }^{+}$ions.

The authors of work [71] have proposed an aqueous composition for surface friction reduction containing a solid lubricant and a modified, or synthetic, clay mineral. The clay minerals are smectites such as saponite, montmorillonite, hectorite etc. The share of solid lubricant is usually $1 \mathrm{wt} \%$ of the aqueous composite, more rarely $3 \%$ to $40 \%$. The clay mineral is modified via pre-mixing with a water-soluble organic polymer in water, followed by spray drying. If necessary, the resulting dried mixture is ground to the size of $1 \mu \mathrm{m}$ to $20 \mu \mathrm{m}$. The content of water-soluble polymer in the mixture is $0.1 \mathrm{wt} \%$ to $40 \mathrm{wt} \%$.

The invention described in [72] proposes the process of a granular adsorbent characterized by high hardness, water-resistance, and adsorbing performance. The granular adsorbent is obtained by mixing 0.1 to 300 weight parts of a layered silicate mineral with 100 weight parts of an alkali metal hydroxide, which is followed by pelletizing and calcining. The hydroxides of magnesium, calcium, etc. are used. The mineral layered silicate is a natural mineral such as saponite, montmorillonite, beidellite, kaolinite, bentonite, etc. If needed, inorganic fibers, a pigment or an antibacterial agent can be added. The recommended adsorbent size is 0.5 to $10 \mathrm{~mm}$.

The authors of work [73] propose an effective composition for eliminating metal pollution based on a composite containing a substrate, an organic ion, and a metal-binding agent. The substrate contains saponite, montmorillonite, natural and synthetic zeolite, polymer resin, lignite, kaolinite or a combination thereof. The organic ion includes quaternary amines, imidazolium salts, phosphonium salts, tetra alkyl ammonium, bis-(hydrogenated tallow)-dimethyl-ammonium chloride, bis-(hydrogenated tallow)-benzyl-methyl-ammonium chloride, 4,5-dihydro-1-methyl-2-nortallow-alkyl-1-(2-tallow-amidoethyl)-imidazolium methyl sulfate, 1-ethyl-4,5-dihydro-3-(2-hydroxyethil)-2-(8-heptadecenyl); -imidazolium ethyl sulfate, or combinations thereof. The metal-binding agent comprises mercaptan, carboxylic acid, chelating agents, amines, esters, 
carboxylic acids, alcohols, ethers, aldehydes, ketones, alkenes, mercaptans, thiols, tert-dodecanethiol, nonanethiol, octanethiol, n-stearic acid, palmitic acid, or combinations thereof.

\subsection{Saponite in Nanocomposite, Textile and Paper Manufacture}

Saponite is well known in the manufacturing of polymeric and polymer-ceramic composites, nano-composites, textile and paper [74-86].

Nityashree and coauthors [74] have synthesized some nanocomposites, where the layers of anionic clay are intercalated between the layers of cationic clay, by mixing an aqueous colloid dispersion of laminated copper hydroxide layers, or $\alpha$-cobalt hydroxide, with an aqueous colloid dispersion of saponite. The thermal decomposition behavior of nano-composites, resembling a chlorite-like mineral with metal hydroxide layers intercalated between saponite layers, and of original layered solid substances was different. Thermal cracking of the chlorite-like nanocomposites caused the emergence of metal oxide nano-particles $\left(\mathrm{CuO} / \mathrm{Co}_{3} \mathrm{O}_{4}\right)$ uniformly distributed throughout the saponite matrix. The obtained oxide nano-particles can be of different sizes by varying decomposition time and temperature.

W. Wang and coauthors [75] have proposed and researched some nanocomposites consisting of quaternary fulvic acid (QFA) and saponite. The fulvic acid (FA) was obtained from sodium humate and nitric acid and further synthesized into QFA. The QFA-intercalated saponite (QFA-saponite) was prepared by using ultrasonic radiation. In order to improve the thermal and mechanical characteristics of polylactic acid (PLA), the QFA-saponite/PLA nano-composites were obtained from QFA-saponite and PLA via the solution intercalation. Anti-bacterial properties of QFA-saponite/PLA nano-composites have been investigated. Due to nano-size of QFA-saponite dispersion in the PLA matrix, the composites had better thermal and mechanical properties compared to pure PLA. The thermal and mechanical properties of the composites were optimal when the QFA-saponite content was $1 \mathrm{wt} \%$. Moreover, the QFA-saponite/PLA nano-complexes were found to possess high bacteriostatic activity.

The authors of [76] have proposed a technique yielding a nanocomposite material from a composite consisting of $5 \mathrm{wt} \%$ to $90 \mathrm{wt} \%$ of synthetic thermoplastic polymer (polyopheline), a nanosize filler obtained from natural or synthetic phyllosilicates or laminated silicate clay (saponite, montmorillonite, etc.) ( $5 \mathrm{wt} \%$ to $80 \mathrm{wt} \%)$, and a deflocculating agent obtained by controlled free-radical polymerization ( $5 \mathrm{wt} \%$ to $50 \mathrm{wt} \%$ ).

Work [77] also proposes a polyolephynic nanocomposite process incorporating stirring in a melt at $120-290{ }^{\circ} \mathrm{C}$ of a mixture of polyophylline, a filler (1 to $15 \%$ in terms of polyolephyne) represented by a laminated silicate clay (saponite, montmorillonite, etc.), a laminated hydroxycarbonate or phyllosilicate and a non-ionogenic surface-active material $(0.1$ to $7.5 \%$ in terms of polyolephyne mass). The non-ionogenic surface-active material is a block- or graft-copolymer with hydrophilic (ethylene oxide block) and hydrophobic (polyolephyne, fluorocarbon, siloxane or low-molecular methacrylate) segments. The surface-active non-ionogenic materials can be sorbitan ester, dimethylsiloxane-ethylenoxide copolymer block, or poly(methylmetalkrylate)-poly(oxoethylen) copolymer block.

Nanocomposite materials can be admixed [76,77] with phenol antioxidants, light stabilizers, solvents, pigments, coloring and plasticizing agents, admixtures enhancing impact resistance, thixotropic agents, acid acceptors and/or metal deactivators.

These nanocomposites are used in the manufacturing of foam plastic, fibers, various building, hygienic, packing, insulating and textile materials, strand or molded articles, storage basins, footware, printing forms, image carriers and circuit boards, optic and magnetic materials, furniture, playthings, sports and household items, etc.

The authors of [78] proposed a composite material obtainable at the temperature of $190-220{ }^{\circ} \mathrm{C}$ from thermoplastic (80.0-99.5\%) and a filler (0.5-20\%). The filler is a laminated silicate (saponite, montmorillonite, palygorskite, kaolin, bentonite, etc.) modified by QAS (a quaternary ammonium salt) 
at a silicate to QAS ratio of (2-200):1. This material is used in the manufacturing of technical parts such as plain bearings.

The invention described in work [79] proposes a method for preparation of high-porous composite materials from aluminum oxide and water-swellable clay (saponite, montmorillonite, etc.) homogeneously dispersed in the aluminum oxide component. The average pore diameter of the composite material is $1 \mu \mathrm{m}$ to $150 \mu \mathrm{m}$. Calcining at $537.8^{\circ} \mathrm{C}$ for $2 \mathrm{~h}$ causes the surface area to increase to about $200 \mathrm{~m}^{2} / \mathrm{g}$; the average pore diameter and pore volume are $60 \AA$ to $400 \AA$ and $0.5 \mathrm{~cm}^{3} / \mathrm{g}$ to $2.0 \mathrm{~cm}^{3} / \mathrm{g}$, respectively.

The patent [80] has proposed a polymeric nanocomposite process based on clay with dispersed olefin and polyolefin resin. The nanocomposite is characterized by high stretching and thermal resistance, without a detrimental effect on transparency. The process incorporates immersing of the catalyst and co-catalyst into the clay, followed by olefin immersion, and polymerization thereof. The clay material is montmorillonite, hectorite, saponite, vermiculite, etc. The catalyst of olefin polymerization is an organic complex bonded with one of the following metals: $\mathrm{Zr}, \mathrm{Ti}, \mathrm{Ni}$ and $\mathrm{Pd}$. The co-catalyst represents an alumoorganic compounds, such as $\left(\mathrm{C}_{2} \mathrm{H}_{5}\right)_{3} \mathrm{Al},\left(\mathrm{C}_{2} \mathrm{H}_{5}\right)_{2} \mathrm{AlCl},\left(\mathrm{C}_{2} \mathrm{H}_{5}\right) \mathrm{AlCl}_{2}$, $\left(\mathrm{t}-\mathrm{C}_{4} \mathrm{H}_{9}\right)_{3} \mathrm{Al}$ and (iso- $\left.\mathrm{C}_{4} \mathrm{H}_{9}\right)_{3} \mathrm{Al}$.

The invention [81] proposes a method for preparation of a composite clay material with improved properties whereby the clays are treated with an agent containing $10-80 \mathrm{~mol} \%$ of hydroxoorganic onium ions and vinyl alcohol polymers. The organic onium ions were obtained from an acrylic oligomer with an average molecular mass of 1000-15,000. The feed clay represents laminated clay minerals such as saponite, montmorillonite, etc.

Patent [82] proposes a nanocomposite process based on polymeric clay (montmorillonite, saponite, bentonite, hectorite, etc.) modified with an agent including two or more hydroxyl groups, silanol or alkyldiisocyanate with carbon atom values of 2-10.

P. O'Connor and S. Daamen proposed a technique yielding stable biomass suspensions containing inorganic particles [83]. Liquid suspensions containing a suspending medium, fine biomass particles and fine inorganic particles have been developed. The suspensions are stabilized due to the presence of fine $(3 \mathrm{~mm}$ to $50 \mu \mathrm{m}$ ) inorganic material (saponite, alumina, transition metals hydroxides, sepiolite, etc.), which makes it possible to avoid sludging during the pipeline or cistern transportation. The suspensions are used in biofuel manufacture. The biomass contains polymeric materials such as cellulose and lignocellulose. The liquid suspension medium may also contain either water or alcohol, or carbonic acid. The process of biomass suspension manufacture can be accelerated by varying the temperature, $\mathrm{pH}$ and evaporation of the liquid suspension medium, individually or in combination.

The authors of [84] have demonstrated the advantages of microwave synthesis yielding mesoporous acid saponites characterized by a surface area of $603 \mathrm{~m}^{2} / \mathrm{g}$ and lamellae crystallite size of about $4 \mathrm{~nm}$ by using a quaternary ammonium salt, surfactants, or polymer, as template, and researched the effect of the $\mathrm{pH}$, temperature and $\mathrm{H}_{2} \mathrm{O} / \mathrm{Si}$ molecular ratio on the process. Required acidity was obtained by calcination of $\mathrm{NH}_{4}$-form of saponite.

Work [85] proposes a method for the preparation and use of laminar phyllosilicate particles (silicate clay particles), with or without surface modification, with controllable size of 0.05 to $15 \mu \mathrm{m}$. Powders of this type are admixed to plastic or ceramic matrices. Pre-grinding to the size of 5-100 $\mu \mathrm{m}$ is performed in flushing mills in either dry or wet regimes. This is followed by controlled extraction of the particles sized 0.05 to $15 \mu \mathrm{m}$. Extraction is either dry, in dynamic classifiers, or wet, in centrifuges. The surface of phyllosilicate particles is modified using acrylic bioactive materials and acetate, alcohol solutions, or silver, copper, iron, nickel or cobalt salts.

The authors of [86] proposed a method for the production of fire-proof paper, incorporated in fire-proof film laminate for use in heat- and acoustic-insulating systems in civil aviation and other areas. The fire-proof paper contains inorganic biodegradable fibers, organic reinforcing fibers, organic and inorganic fibers or binder and, although not obligatorily, fire-proof ceramic fibers. The inorganic 
binding consists of clay (saponite, bentonite, montmorillonite, etc.) and ground inorganic or ceramic fibers, molten silicon oxide, etc.

\subsection{Saponite in Construction Materials Manufacture}

The recovery of saponite from kimberlite ore concentration waste in the manufacturing of construction materials such as binders, plasters, ceramics, etc., has been widely researched.

Thus, the authors of works $[2,87,88]$ propose a method for the pelletizing of iron-ore concentrates and producing high-quality building materials.

In works [89-91], it is proposed to utilize clays with saponite composition as binders in the manufacturing of steam-cured silicate materials.

Kim Dae Hee developed a method for the production of construction plastering mortar from natural minerals, including clays [92]. Compared to conventional cement mortars, the resulting mixture is characterized by low fissuring, better acoustic absorption, adhesion and initial strengths.

Work [93] proposes a method for controlling the water-cement ratio in mortar curing by adding a fine saponite-containing product obtained from kimberlite ore concentration waste. As a result of a $7 \%$ addition of saponite-containing material, the concrete strength increased 2-fold and the frost-resistance quality was improved to F150.

It has been proved that thickened saponite-containing material can be recovered in ceramic brick manufacture [94]. The maximum compressive strength of the samples was $13 \mathrm{MPa}$. The authors also obtained a 250 quality cement clinker ( $75 \%$ of lime and $25 \%$ of thickened saponite-containing product) usable in the manufacturing of Portland cement.

Modified saponite-containing product has been used to produce high-quality ceramic bricks (Figure 6), with compressive and bending strengths of $800-1000{ }^{\circ} \mathrm{C}$ of $61.3 \pm 2.8-80.9 \pm 3.6 \mathrm{MPa}$ and $11.9 \pm 1.7-26.7 \pm 2.1 \mathrm{MPa}$, respectively, within the sintering temperature range [30,95]. The bulk density, water absorption and fire shrinkage of ceramic materials at various sintering temperatures are presented in Figure 7. As expected, sample density increased with increase of sintering temperature: $1.9 \pm 0.1 \mathrm{~g} / \mathrm{cm}^{3}\left(800^{\circ} \mathrm{C}\right)-2.2 \pm 0.2 \mathrm{~g} / \mathrm{cm}^{3}\left(100{ }^{\circ} \mathrm{C}\right)$. Water absorption diminished from $13.6 \pm 0.4 \%$ $\left(800{ }^{\circ} \mathrm{C}\right)$ to $11 \pm 0.3 \%\left(1000{ }^{\circ} \mathrm{C}\right)$. The fire shrinkage values in the examined sintering temperature range were: $1.15 \pm 0.22 \%\left(800^{\circ} \mathrm{C}\right)-3.2 \pm 0.3 \%\left(1000{ }^{\circ} \mathrm{C}\right)$.

It is of interest to continue researching the applicability of saponite-containing concentrates in pellets manufacture and using the electrochemically obtained concentrates as drilling mud components due to small dimensions (less than $7 \mu \mathrm{m}$ ) of quartz particles in the concentrate.

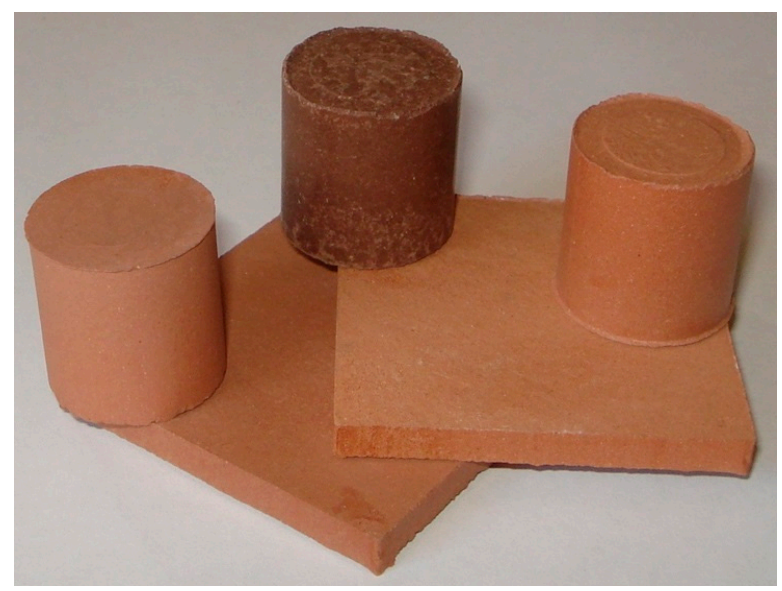

Figure 6. Ceramic samples obtained from modified saponite product. 

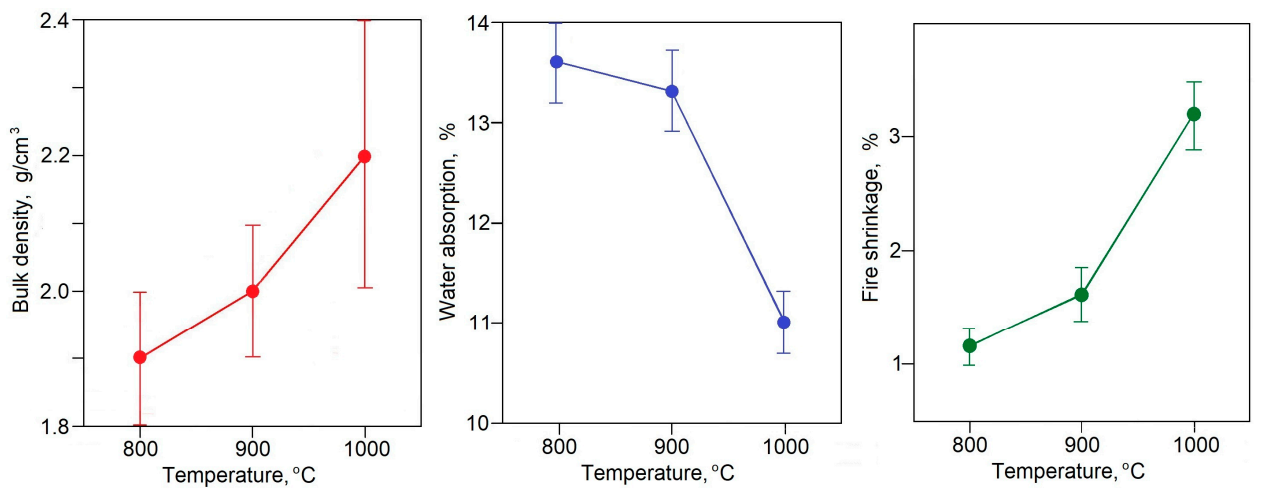

Figure 7. Dependences of bulk density, water absorption and fire shrinkage of ceramic materials obtained from modified saponite product on sintering temperature.

\section{Conclusions}

Analyses of the capacity, mining and concentration techniques, and saponite-containing waste recycling, as well as the research of structural and mineral composition of saponite-containing products carried out at the Lomonosov kimberlite deposit, has led us to conclusions on the preferability of methods of cryogenic treatment and electrochemical separation in the purification of recycling water at Lomonosov GOK plants.

Electrochemical separation helps obtain modified saponite-containing products with high smectite-group minerals concentrations, lower mineral particles size, more compact structure, and greater surface area. These characteristics open possibilities for the manufacture of high-quality ceramics and heavy-metal sorbents from saponite-containing products.

The application area of saponite-containing products should be extended by utilizing them in iron-ore pellet production and as drilling fluid components.

It was also shown that pure saponite is a valuable material for different industries, especially in the manufacturing of composites and other advanced materials. Therefore, the new methods for thickening and purification of saponite concentrate from Lomonosov deposit and producing of pure saponite represent a considerable scientific and practical interest. The properties exhibited by electrochemically modified saponite are also intriguing and potentially useful.

Author Contributions: Conceptualization, V.A.C., V.G.M., D.V.M., O.V.S. and E.A.S.; Methodology, V.A.C., V.G.M., D.V.M., O.V.S. and E.A.S.; Investigation, V.A.C., V.G.M., D.V.M., O.V.S. and E.A.S.; Writing-Original Draft Preparation, V.A.C., V.G.M., D.V.M., O.V.S. and E.A.S.; Writing-Review \& Editing, V.A.C., V.G.M., D.V.M., O.V.S. and E.A.S.; Visualization, V.A.C., V.G.M., D.V.M., O.V.S. and E.A.S.

Funding: This research was funded by Russian Government grant 01201374315 (0138-2014-0002).

Acknowledgments: We are grateful to anonymous referees whose comments improve the manuscript greatly.

Conflicts of Interest: The authors declare no conflict of interest.

\section{References}

1. Karpenko, F.S. Saponite-Containing Precipitation Accumulation Conditions and Thickening in Tailing Ponds of Lomonosov Diamond Deposit. Ph.D. Thesis, Sergeev Institute of Environmental Geoscience RAS, Moscow, Russia, 2009. (In Russian)

2. Bezborodov, S.M.; Verzhak, V.V.; Verzhak, D.V.; Garanin, V.K.; Garanin, K.V.; Zuev, V.M.; Kudryavtseva, G.P.; Pylaev, N.F. Way of Recycling Diamond Industry Wastes. RU Patent 2,206,534, 20 June 2003.

3. The official IMA-CNMNC List of Mineral Updated List of IMA-Approved Minerals (November 2018). Available online: http://ima-cnmnc.nrm.se/IMA_Master_List_\%282018-11\%29.pdf (accessed on 26 November 2018).

4. Mindat.org. Smectite Group. Available online: https://www.mindat.org/min-11119.html (accessed on 26 November 2018). 
5. Odom, I.E. Smectite clay minerals: Properties and uses. Philos. Trans. R. Soc. A 1984, 311, 391-409. [CrossRef]

6. Guggenheim, S.; Adams, J.M.; Bain, D.C.; Bergaya, F.; Brigatti, M.F.; Drits, V.A.; Formoso, M.L.L.; Gala'n, E.; Kogure, T.; Stanjek, H. Summary of recommendations of nomenclature committees relevant to clay mineralogy: Report of the Association Internationale pour 1'Etude des Argiles (AIPEA) Nomenclature Committee for 2006. Clay Miner. 2006, 41, 863-877. [CrossRef]

7. Laird, D.A. Influence of layer charge on swelling of smectites. Appl. Clay Sci. 2006, 34, 74-87. [CrossRef]

8. Decarreau, A.; Bonnin, D. Synthesis and crystallogenesis at low temperature of Fe(III)-smectites by evolution of coprecipitated gels: Experiments in partially reducing conditions. Clay Miner. 1986, 21, 861-877. [CrossRef]

9. Jasmund, K.; Lagaly, G. Tonminerale und Tone. Struktur, Eigenschaften, Anwendung und Einsatz in Industrie und Umwelt; Steinkopff Verlag: Darmstadt, Germany, 1993; p. 490.

10. Ogorodova, L.P.; Kiseleva, I.A.; Mel'chakova, L.V.; Vigasina, M.F.; Krupskaya, V.V.; Sud'in, V.V. Calorimetric determination of the enthalpy of formation of natural saponite. Geochem. Int. 2015, 53, 617-623. [CrossRef]

11. Christidis, G.E. The concept of layer charge of smectites and its implications for important smectite-water properties. EMU Notes Mineral. 2011, 11, Chapter 6. 239-260.

12. Alietti, A.; Mejsner, J. Structure of a talc/saponite mixed-layer mineral. Clay Clay Min. 1980, 28, 388-390. [CrossRef]

13. Eberl, D.D.; Jones, G.; Khoury, H.N. Mixed-layer kerolite/stevensite from the Amargosa Desert, Nevada. Clay Clay Min. 1982, 57, 115-133. [CrossRef]

14. Steudel, A.; Friedrich, F.; Schuhmann, R.; Ruf, F.; Sohling, U.; Emmerich, K. Characterization of a fine-grained interstratification of turbostratic talc and saponite. Minerals 2017, 7, 5. [CrossRef]

15. Breukelaar, J.; van Santen, R.A.; De Winter, A.W. Synthetic Saponite-Derivatives, a Method for Preparing Such Saponites and Their Use in Catalytic (Hydro) Conversions. US Patent 5,089,458, 18 February 1992.

16. Farmer, V.C.; McHardy, W.J.; Elsass, F.; Robert, M. hk-ordering in aluminous nontronite and saponite synthesized near $90{ }^{\circ} \mathrm{C}$ : Effects of synthesis conditions on nontronite composition and ordering. Clay Clay Min. 1994, 42, 180-186. [CrossRef]

17. Grauby, O.; Petit, S.; Decarreau, A.; Baronnet, A. The nontronite-saponite series: An experimental approach. Eur. J. Mineral. 1994, 6, 99-112. [CrossRef]

18. Kuperman, A.E.; Maesen, T.; Dykstra, D.; Uckung, I.J. Magnesium Aluminosilicate Clays-Synthesis and Catalysis. US Patent 20,100,087,313, 8 April 2010.

19. Tkachenko, O.P.; Kustov, L.M.; Kapustin, G.I.; Mishina, I.V.; Kuperman, A. Synthesis and acid-base properties of Mg-saponite. Mendeleev Commun. 2017, 27, 407-409. [CrossRef]

20. Baldermann, A.; Dohrmann, R.; Kaufhold, S.; Nickel, C. The Fe-Mg-saponite solid solution series-A hydrothermal synthesis study. Clay Miner. 2014, 49, 391-415. [CrossRef]

21. Murray, H.H. Applied Clay Mineralogy. Occurrences, Processing and Application of Kaolins, Bentonites, Palygorskite-Sepiolite, and Common Clays; Elsevier B.V.: Oxford, UK, 2007; p. 188.

22. Krupskaya, V.V.; Zakusin, S.V.; Tyupina, E.A.; Dorzhieva, O.V.; Zhukhlistov, A.P.; Belousov, P.E.; Timofeeva, M.N. Experimental study of montmorillonite structure and transformation of its properties under treatment with inorganic acid solutions. Minerals 2017, 7, 49. [CrossRef]

23. Komadel, P. Structure and chemical characteristics of modified clays. In Natural Microporous Materials in Environmental Technology; Misealides, P., Macasek, F., Pinnavaia, T.J., Colella, C., Eds.; Kluwer: Alphen aan den Rijn, The Netherlands, 1999; pp. 3-18.

24. Tkac, I.; Komadel, P.; Muller, D. Acid-treated montmorillonites-A study by ${ }^{29} \mathrm{Si}$ and ${ }^{27} \mathrm{Al}$ MAS NMR. Clay Miner. 1994, 29, 11-19. [CrossRef]

25. Kumar, P.; Jasra, R.V.; Bhat, T.S.G. Evolution of Porosity and Surface Acidity in Montmorillonite Clay on Acid Activation. Ind. Eng. Chem. Res. 1995, 34, 1440-1448. [CrossRef]

26. Vicente, M.A.; Suarez Barrios, M.; Lopez Gonzalez, J.D.; Banares Munoz, M.A. Characterization, surface area, and porosity analyses of the solids obtained by acid leaching of a saponite. Langmuir 1996, 12, 566-572. [CrossRef]

27. Morozova, M.V.; Frolova, M.A.; Makhova, T.A. Sorption-desorption properties of saponite-containing material. J. Phys. Conf. Ser. 2017, 929, 012111. [CrossRef]

28. Minenko, V.G.; Samusev, A.L.; Selivanova, E.A.; Bajurova, J.L.; Silikova, A.R.; Makarov, D.V. Study of copper ions sorption with electrochemically modified saponite. In Proceedings of the Mineralogy of 
Technogenesis-2017, Institute of Mineralogy, Ural Branch of RAS, Miass, Russia, 22-25 June 2017; pp. 190-199. (In Russian)

29. Norrish, K. The swelling of montmorrilonite. Discuss. Faraday Soc. 1954, 18, 120-134. [CrossRef]

30. Chanturiya, V.; Minenko, V.; Suvorova, O.; Pletneva, V.; Makarov, D. Electrochemical modification of saponite for manufacture of ceramic building materials. Appl. Clay Sci. 2017, 135, 199-205. [CrossRef]

31. Asonchik, K.M.; Utin, A.V.; Kovkova, T.M.; Kostrov, A.M. Tailings slurry carbonization plant pilot-scale testing at the Lomonosovsky mining and concentration complex. Obogashchenie Rud (Miner. Process.) 2016, 1, 47-53. [CrossRef]

32. Utin, A.V. Method of Thickening Saponite Suspension. RU Patent 2,448,052, 20 April 2012.

33. Bakharev, S.A. The return water acoustical treatment at a diamonds recovery plant tailings storage facility cell. Obogashchenie Rud (Miner. Process.) 2014, 6, 3-7.

34. Dvoychenkova, G.P.; Minenko, V.G.; Kaplin, A.I.; Kobelev, D.A.; Bychkova, G.M. Experimental substantiation of the use of non-standard methods for recycled water clarification at the processing plants AK ALROSA. In Proceedings of the International Conference "The Plaksin's Readings-2007", Kola Science Centre of RAS, Apatity, Russia, 1-7 October 2007; pp. 332-336. (In Russian)

35. Osipov, V.I.; Karpenko, F.S. Method of Compacting Saponite-Bearing Sediments of Tailings Dumps. RU Patent 2,475,454, 20 February 2013.

36. Chanturiya, V.A.; Minenko, V.G.; Timofeev, A.S.; Dvoychenkova, G.P.; Samofalov, Y.L. Electrochemical method of the extraction of montmorillonite group minerals from the tailing dump waters. Gornyi Zhurnal (Min. J.) 2012, 12, 83-87.

37. Chanturiya, V.A.; Minenko, V.G.; Samusev, A.L.; Timofeev, A.S.; Ostrovskaya, G.K. Electrochemical separation of OAO «Severalmaz» facilities saponite-containing tailings pulp. Obogashchenie Rud (Miner. Process.) 2014, 1, 49-52.

38. Minenko, V.G. Justification and design of electrochemical recovery of saponite from recycled water. J. Min. Sci. 2014, 50, 595-600. [CrossRef]

39. Chanturiya, V.A.; Minenko, V.G.; Samusev, A.L.; Dvoychenkova, G.P.; Kur'janov, M.B.; Timofeev, A.S. Method of Deslimation of Circulating Saponite-Containing Waters and Device Its Implementation. RU Patent 2,529,220, 27 September 2014.

40. Chanturiya, V.A.; Trofimova, E.A.; Bogachev, V.I.; Minenko, V.G.; Dvoychenkova, G.P.; Kur'janov, M.B.; Timofeev, A.S. Method of Extraction of Saponite-Containing Substances from Return Water and Device for Its Implementation. RU Patent 2,535,048, 10 December 2014.

41. Osipov, V.I.; Sokolov, V.N. Clays and Their Properties. Composition, Structure and Formation of Properties; GEOS: Moscow, Russia, 2013; p. 576. (In Russian)

42. National Standard of Ukraine DSTU 7110:2009. Saponite Meal. Ameliorant of the Combined Action. General Specifications. Available online: http:/ / document.ua/boroshno-saponitove.-meliorant-kompleksnoyi-diyi. -zagalni-te-std3600.html (accessed on 26 November 2018).

43. National Standard of Ukraine DSTU 4906:2008. Food for Animals. Polimineral Substances Based Saponitis and Glauconitis for Broiler Chickens. Specifications. Available online: http:/ / document.ua/kormi-dljatvarin_-preparati-polimineralni-na-osnovi-saponit-std36156.html (accessed on 26 November 2018).

44. Derecha, O.A.; Klyuchevich, M.M. Composition for Presowing Treatment of Winter Wheat Seeds. UA Patent 54,892, 17 March 2003.

45. Frisch, G.; Maier, T. Thixotropic Aqueous Plant Protection Agent Suspensions. CA Patent 2,158,711, 22 March 1996.

46. Kulik, M.F.; Velichko, I.N.; Ovsienko, A.I.; Khimich, V.V.; Gricyk, V.E.; Vasilenko, S.V.; Gerasimchuk, A.P. Method of Obtaining Food for Pigs. SU Patent 1,748,780, 23 July 1992.

47. Karunskyi, O.Y.; Nikil'bursky, M.I.; Riznichuk, I.F. Amidoconcentrate Mineral Additive Kanir-3. UA Patent 48,445, 15 August 2002.

48. Roik, M.V.; Hurskyi, D.S.; Barshtein, L.A.; Heiko, V.D.; Musich, V.I.; Metalidi, V.S.; Zaryshniak, A.S.; Boiko, V.S.; Cherednychok, I.I.; Yanov, V.P. Method for Improving the Agrochemical Properties of Ammonium Nitrate. UA Patent 46,004, 15 May 2002.

49. Tomoko, S.; Kanemaru, T.; Matsuzaki, F.; Yanaki, T. Powdery Composition. Patent EP 1,402,875, 31 March 2004. 
50. Tokubo, K.; Yamaguchi, M.; Suzuki, J.; Yoshioka, T.; Kanda, F.; Fukuda, M.; Ikeda, T.; Kawaura, T.; Yagita, Y. Spherical Clay Mineral Powder, Process for Production Thereof and Composition Containing the Same. US Patent 5,165,915, 24 November 1992.

51. Takuo, S.; Kenji, S. Ultraviolet Absorbent Composition and Cosmetic Containing the Same. JP Patent 60,081,124, 9 May 1985.

52. Takeshi, Y.; Tomiyuki, N. Composition for Skin and Hair. JP Patent 63,275,507, 14 November 1988.

53. Herve, D.; Jocelyne, B.; Maguy, J.; Lucia, L.A. Procede D'exfoliation D’argiles Intercalees. FR Patent 2,882,997, 15 September 2006.

54. Klein, W.; Kaden, W.; Röckl, M. Desodorierende Kosmetische Mittel (Deodorizing Cosmetic Products). DE Patent 4,009,347, 26 September 1991.

55. Decoster, S.; Beauquey, B.; Cotteret, J. Composition Cosmetiques Detergents et Utilisation (Cosmetic Detergent Composition and Utilization). FR Patent 2,722,091, 12 January 1996.

56. Upadek, H.; Schwadtke, K.; Seiter, W.; Pioch, L. Granulares, Phosphatfreies Wasserenthartungsmittel (Granular, Phosphate-Free Water Softener). DE Patent 3,931,871, 4 April 1991.

57. Hoeghst, A.G. Granulierte Blaichaktivatoren und Ihre Herstellung (Granulated Bleach Activators and Their Preparation). DE Patent 4,439,039, 9 May 1996.

58. Matsui, M.; Yamamoto, H. Process for the Preparation of Tocopherol Derivatives and Catalyst. US Patent 5,536,852, 16 July 1996.

59. Koga, S.; Sugiyama, H.; Suzuki, K. Preparation of Clay Mineral Containing Metal. JP Patent 02,116,611, 1 May 1990.

60. Hong, S.I.; Park, H.W.; Cho, Y.J.; Rhim, J.W. Antimicrobial Nano-Particle Clay and Manufacturing Method. Thereof. Patent KR 20,080,075,813, 19 August 2008.

61. Uddin, M.K. A review on the adsorption of heavy metals by clay minerals, with special focus on the past decade. Chem. Eng. J. 2017, 308, 438-462. [CrossRef]

62. Bhattacharyya, K.G.; Gupta, S.S. Removal of $\mathrm{Cu}(\mathrm{II})$ by natural and acid-activated clays: An insight of adsorption isotherm, kinetic and thermodynamics. Desalination 2011, 272, 66-75. [CrossRef]

63. Petra, L.; Billik, P.; Melichová, Z.; Komadel, P. Mechanochemically activated saponite as materials for $\mathrm{Cu}^{2+}$ and $\mathrm{Ni}^{2+}$ removal from aqueous solutions. Appl. Clay Sci. 2017, 143, 22-28. [CrossRef]

64. Minenko, V.G.; Makarov, D.V.; Samusev, A.L.; Suvorova, O.V.; Selivanova, E.A. New efficient techniques of saponite recovery from process water of diamond treatment plants yielding high-quality marketable products (abstract). In Proceedings of the XXIX International Mineral Processing Congress, Moscow, Russia, 17-21 September 2018; pp. 187-188.

65. Parthasarathy, G.; Sreedhar, B.; Boyapati, M.C. Method for Adsorption and Reduction of Hexavalent Chromium by Using Ferrous-Saponite. US Patent 2,006,016,757, 26 January 2006.

66. Pshinko, G.N.; Kobets, S.A.; Bogolepov, A.A.; Goncharuk, V.V. Treatment of waters containing uranium with saponite clay. J. Water Chem. Technol. 2010, 32, 10-16. [CrossRef]

67. Mizukami, N.; Tsujimura, M.; Kuroda, K.; Ogawa, M. Preparation and characterization of Eu- magadiite intercalation compounds. Clay Clay Miner. 2002, 50, 799-806. [CrossRef]

68. Villa-Alfagemea, M.; Hurtado, S.; Castro, M.; Mrabet, S.; Orta, M.; Pazosc, M.; Alba, M. Quantification and comparison of the reaction properties of FEBEX and MX-80 clays with saponite: Europium immobilisers under subcritical conditions. Appl. Clay Sci. 2014, 101, 10-15. [CrossRef]

69. Holmgren, J.S.; Schoonover, M.W.; Gembicki, S.A.; Kocal, J.A. Catalysts Containing Homogeneous Layered Clay/Inorganic Oxide. Patent EP 0,568,741, 10 November 1993.

70. Kraft, A. Method for Preparing Polymers of Glycerol with a Saponite Catalyst. US Patent 20,030,105,274, 5 June 2003.

71. Nozoe, T.; Tsuji, Y.; Black-Wood, W.; Kojima, K.; Ozaki, M.; Hori, S. Friction Reducing Coatings. Patent WO 2,011,082,137, 27 October 2010.

72. Ota, S.; Kurosaki, K. Production of Granular Adsorbent. Patent JP 10,137,581, 26 May 1998.

73. Angeles-Boza, A.M.; Landis, C.R.; Shumway, W.W. Composition and Method for Removing Metal Contaminants. US Patent 2,012,261,609, 18 October 2012.

74. Nityashree, N.; Gautam, U.K.; Rajamathi, M. Synthesis and thermal decomposition of metal hydroxide intercalated saponite. Appl. Clay Sci. 2014, 87, 163-169. [CrossRef] 
75. Wang, W.; Zhen, W.; Bian, S.; Xi, X. Structure and properties of quaternary fulvic acid-intercalated saponite/poly (lactic acid) nanocomposites. Appl. Clay Sci. 2015, 109-110, 136-142. [CrossRef]

76. Moad, G.; Sajmon, D.F.; Din, K.M.; Li, G.; Mejjadann, R.T.A.; Vermter, K.; Pfehndner, R. Dispersants in Nanocomposites. RU Patent 2,404,208, 20 November 2010.

77. Moad, G.; Sajmon, D.F.; Din, K.M.; Li, G.; Mejjadann, R.T.A.; Pfehndner, R.; Vermter, K.; Shnajder, A. Method of Preparing Polyolefin Nanocomposites. RU Patent 2,360,933, 10 July 2009.

78. Burmistr, M.V.; Sukhyi, K.M.; Ovcharov, V.I.A. Composition Material. Patent UA 77,823, 15 January 2007.

79. Ljuss'er, R.Z.; Plesha, S.; Vehar, C.S.; Uiterbi, G.D. Hydrothermally Stable High-Porous Composite Materials of the Type Alumina/Swelled Clay and Methods for Preparation and Use Thereof. RU Patent 2,264,254, 20 November 2005.

80. Jin, Y.H.; Kim, J.A.; Kim, J.G.; Kwak, S.J.; Park, H.J.; Park, M. Preparation Method of Clay-Dispersed Olefin-Based Polymer Nanocomposite. Patent KR 20,030,025,308, 29 March 2003.

81. Usuki, A.; Hiruta, O.; Okada, A. Composite Clay Material. Patent JP 10,158,459, 16 June 1998.

82. Hwang, S.Y.; ImSeung, S. Modified clay, A Treating Method Thereof, Clay-Polymer Nanocomposite and a Manufacturing Method Thereof. Patent KR 20,100,068,823, 24 June 2010.

83. O'Connor, P.; Daamen, S. Stable Suspensions of Biomass Comprising Inorganic Particulates. Patent WO 2,008,020,046, 21 February 2008.

84. Gebretsadik, F.; Mance, D.; Baldus, M.; Salagre, P.; Cesteros, Y. Microwave synthesis of delaminated acid saponites using quaternary ammonium salt or polymer as template. Study of pH influence. Appl. Clay Sci. 2015, 114, 20-30. [CrossRef]

85. Lagaron, C. Method for Obtaining Laminar Phyllosilicate Particles Having Controlled Size and Products Obtained Using Said Method. Patent WO 2,011,101,508, 25 August 2011.

86. Garvi Chad, E. Fire-Proof Film Laminate. RU Patent 2,448,841, 27 April 2012.

87. Apollonov, V.N.; Verzhak, V.V.; Garanin, K.V.; Garanin, V.K.; Kudrjavtzeva, G.P.; Shlykov, V.G. Saponite from the Lomonosov diamond deposit. Izv. Vuzov. Geol. Razved. 2003, 3, 20-37. (In Russian)

88. Posukhova, T.V.; Dorofeev, S.A.; Garanin, K.V.; Siaoin, G. Diamond industry wastes: Mineral composition and recycling. Mosc. Univ. Geol. Bull. 2013, 68, 96-107. [CrossRef]

89. Volodchenko, A.N. Cementing based magnesial clays for autoclave silicate material. In Proceedings of the International Conference: Scientific researches and their practical application. Modern state and ways of development, Odessa, Ukraine, 2-12 October 2012; pp. 38-42.

90. Volodchenko, A.N.; Zhukov, R.V.; Lesovik, V.S. Silicate-based materials overburden Arkhangelsk diamond province-ray. Univ. N. North Cauc. Reg. Tech. Sci. Ser. 2006, 3, 67-70. (In Russian)

91. Volodchenko, A.N. Effect of mechanical activation of lime-saponite binding on the properties of silicate materials autoclave. Bull. BSTU Named V.G. Shukhov 2011, 3, 12-16. (In Russian)

92. Kim, D.H. Manufacturing Method of Construction Plastering Mortar Using Natural Minerals. Patent KR 20,020,026,897, 12 April 2012.

93. Morozova, M.V.; Ayzenstadt, A.M.; Makhova, T.A. The use of saponite-containing material for producing frost-resistant concretes. Ind. Civ. Constr. 2015, 1, 28-31. (In Russian)

94. Oblitcov, A.Y.; Rogalev, V.A. Prospective ways of diamondiferous rock enrichment wastes utilization at M.V. Lomonosov diamond deposit. Proc. Min. Inst. 2012, 195, 163-167. (In Russian)

95. Chanturiya, V.A.; Minenko, V.G.; Samusev, A.L.; Masloboev, V.A.; Makarov, D.V.; Suvorova, O.V. Method of Manufacturing Wall Products and Tiles. RU Patent 2,640,437, 9 January 2018.

(C) 2018 by the authors. Licensee MDPI, Basel, Switzerland. This article is an open access article distributed under the terms and conditions of the Creative Commons Attribution (CC BY) license (http://creativecommons.org/licenses/by/4.0/). 